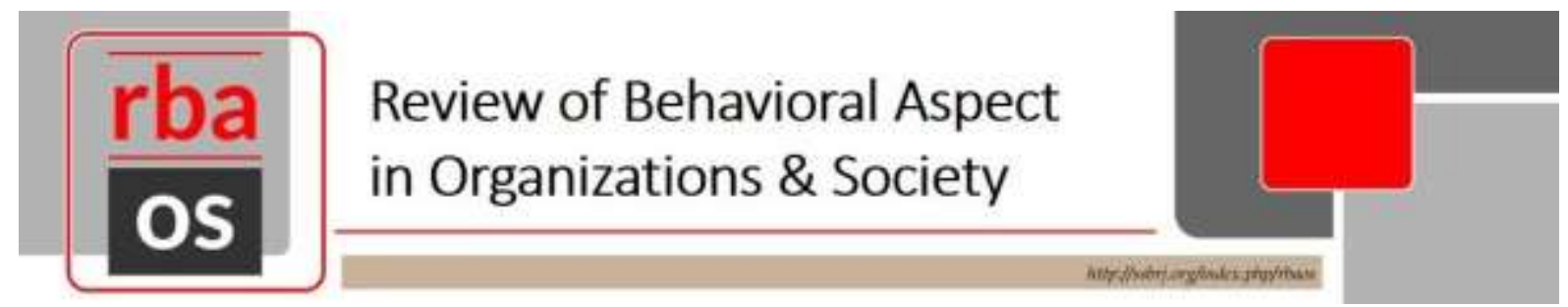

\title{
GREEN TECHNOLOGY THROUGH POROUS CONCRETE
}

\author{
Acep Hidayat, Mercu Buana University, Indonesia \\ Muhammad Isradi, Mercu Buana University, Indonesia \\ Joewono Prasetijo, University Tun Hussein Onn Malaysia, Malaysia
}

\begin{abstract}
This research uses stone ash waste from the stone crusher industry to preserve the environment. This material is an ingredient in making normal concrete. The use of stone ash as a substitute for sand is expected to increase the compressive strength in the planned slump and can optimize the use of rock ash waste to reduce environmental pollution that occurs. This study uses an experimental method with a total of 32 pieces of specimens. Each variation consists of 3 samples with a variety of fine aggregate levels of $40 \%, 44 \%$, and $46 \%$. The test object is a concrete cylinder with a diameter of $15 \mathrm{~cm}$ and a height of $30 \mathrm{~cm}$. Test results for compressive strength at seven days for fine aggregate content variations of 40\%: $22.25 \mathrm{Mpa}$; 44\%: 24.30 Mpa; 46\%: $17.08 \mathrm{MPa}$. Test results of compressive strength at the age of 14 days for variations in fine aggregate levels of 40\%: 26.10 Mpa; 44\%: $28.51 \mathrm{Mpa}$; 46\%: 20.04 Mpa. Test results of compressive strength at the age of 21 days for fine aggregate content variations of $40 \%: 28.18$ Mpa; 44\%: $30.78 \mathrm{Mpa}$; 46\%: 21.63 MPa. With these results, the Porous concrete produced can be used as preservation and maintain environmental protection. This product very cheap when compared to the original concrete, which calculated $22 \mathrm{U} \$$ per square. The use of porous concrete has an impact on people's behavior that will preserve the environment, especially water content in the soil.
\end{abstract}

Keywords: stone ash, concrete, mix design, slump, compressive strength 


\section{Introduction}

In concrete mixes, aggregates fill most of the concrete volume, between $50 \%$ to $80 \%$, so that the nature and quality of the aggregate greatly affect the compressive strength of concrete. A good aggregate will minimize the pores in the concrete so that the strength is better.

Sand, as fine aggregate, is obtained from the mining process in nature, its limited availability and development in Indonesia that continues to grow causing massive exploitation. The exploitation leads to scarcity of sand, and sand that is still available will become more expensive. The high price of sand does not necessarily mean that it must reduce the quality to reduce manufacturing costs, but it is necessary to have a study to find alternatives to replace the sand. One alternative to replace sand is stone ash. Stone ash itself is a siding material or residual production from the processing of crushed stone used stone crusher.

Concrete's versatility, durability, sustainability, and economy have made it the world's most widely used construction material. Concrete is a mixture of cement, fine aggregates, coarse aggregates, and water. The materials are proportioned and mixed to produce concrete suited to the particular job for which it is intended.

The paste is typically made up of Portland cement and water and may also contain supplementary cementing materials (SCMs), such as fly ash or slag cement, and chemical admixtures.

Two important aspect

$>$ compressive strength

$>$ durability

Alkaline with a $\mathrm{pH}$ value of 12 to 13 - avoid the steel bar in concrete from corrosion weakness - not strong to support tensile strength, which only $10 \%$ from the compressive strength. The performance of concrete is related to workmanship, mix proportions, material characteristics, and adequacy of curing. In the journal about price discrimination as a Marketing Strategy, this study confirms that price discrimination would not only work for monopolistic firms, as we have learned in this classic economic analysis but also works effectively as an essential element in a marketing strategy (Alhabeeb, 2019)

In the article by Alhabeeb (2019) it says that the primary objective for this practice is to take the opportunities to increase revenue and ultimately maximize profits. In a more technical term, it is a managerial/marketing strategy to efficiently capture the highest of the consumer surplus by extracting the maximum amount each customer is willing to pay. In the sense of this research trying to attract consumers to be interested in buying and using this product to help protect the environment.

\section{Methodology}

Materials as a basis for concrete mix must be good materials and meet the applicable standards. Testing and inspection of materials and specimens are carried out based on the rules in the American Society for Testing and Materials (ASTM) and the Indonesian National Standard SNI 03-1750-1990 on the quality and methods of concrete aggregate testing. In this case, testing of the characteristics of stone ash is carried out, and also testing of the split or coarse aggregate itself included in the concrete composition material. 


\section{Classification of Concrete}

$>$ The selection of concrete depends on the design requirements and the suitability of the environment, i.e. concrete with strength $70 \mathrm{~N} / \mathrm{mm} 2$ suitable for high rise building but not economy for the normal building

$>$ High strength concrete suitable for high rise building but not economical for normal building

$>$ Concrete can be classified based on:

$$
\begin{array}{ll}
\checkmark & \text { density of aggregate } \\
\checkmark & \text { compressive strength } \\
\checkmark & \text { performance } \\
\checkmark & \text { durability }
\end{array}
$$

$>$ Chemical Admixture

(1) Set Accelerator

$\checkmark$ speed the hydration process of the mixture

$\checkmark$ useful during cold weather pours.

$\checkmark$ Common accelerator - $\mathrm{CaCl} 2$

$\checkmark$ Max 2\% based on cement weight

$\checkmark$ Strength at age $3 \mathrm{~d}>$ strength of normal concrete (25\%)

$\checkmark$ Early removal of form

$\checkmark$ Early use of structure

(2) Set retarder

$\checkmark$ slowing the set

$\checkmark$ enabling delivery to distant sites and finishing during hot weather

$\checkmark$ If too much the concrete will not harden

(3) Water reducing admixture

$\checkmark \quad$ Known as superplasticizer

$\checkmark$ increasing the mix flowability

$\checkmark \quad$ allows the use of less water in the mix design - reduce the amount of water required up to $30 \%$ (depend on the types of admixture used)

$\checkmark \quad$ The hydration process is better and effective which cause CSH gel increase - strength higher than normal concrete

$\checkmark \quad$ increased strength (high strength concrete) and durability of the concrete.

$\checkmark$ Advantages

$\checkmark \quad$ Low W/C ratio (0.3-0.4) with excellent workability

$\checkmark$ Reduced the labor cost for pouring and compaction

$\checkmark \quad$ Increase the early strength of concrete

$\checkmark \quad$ Reduce the segregation between a concrete mixture

(4) Air-entraining Agents

$\checkmark$ Air-entraining agents are chemicals that are added to concrete to improve its freezethaw resistance.

$\checkmark$ Concrete typically contains a large number of pores with different sizes, which may be partially filled with water.

$\checkmark$ If the concrete is subjected to freezing temperatures, this water expands when forming ice crystals and can easily fracture the cement matrix, causing damage that increases with each freeze-thaw cycle. 
$\checkmark$ If the air voids created by the air-entraining agent are of the right size and average spacing, they give the freezing water enough space to expand, thereby avoiding the damaging internal stresses.

$\checkmark$ Air void increase - strength decrease

\section{Pozzolanic Admixture}

$\checkmark$ Materials containing the silica or silica and alumina which, in the presence of water, will react with lime to produce cementitious materials with excellent structural properties

$\checkmark$ Natural materials or waste from industry or agricultural i.e. POFA, RHA, FA, etc

$\checkmark$ Size - normally passing $45 \mu \mathrm{m}$ sieve (fineness of this materials could influence the reaction in the concrete mixture)

$\checkmark$ Main properties - should have silica content $(\mathrm{SiO} 2)$ to react with the calcium hydroxide $(\mathrm{Ca}(\mathrm{OH}) 2)$

$\checkmark$ Replacement level depends on the type and quality of pozzolanic materials

$\checkmark$ They generally improve the workability, density and long-term strength of concrete, durability, economy, early strengths

\section{Effect of Pozzolanic Materials on Concrete}

$\checkmark$ The use of FA, POFA, RHA- reduce the early strength of concrete

$\checkmark$ Two-stage of reaction

- Stage 1 - hydration process

- Stage 2 - pozzolanic reaction (after calcium hydroxide produced during the hydration process)

$\checkmark$ Reduce the heat of hydration because of cement content reduced

\section{Water Cement Ratio}

$\checkmark$ the strength of the concrete depends on the relative quantity of water compared with the cement.

$\checkmark$ w/c - where w represents the mass of water, and c represents the mass of cement.

$\checkmark$ w/cm $-\mathrm{cm}$ represents the mass of cementing materials, which includes the Portland cement plus any supplementary cementing materials such as fly ash, slag cement, or silica fume.

\section{Result}

The tests conducted on fine aggregate in this study include testing the content of mud, specific gravity, and gradation of rock ash. After testing, the test results are presented in Table 1.

Table 1. Results of Fine Aggregate Testing

\begin{tabular}{|c|c|c|c|}
\hline $\begin{array}{l}\text { Type of Tube } \\
\text { Mud Testing }\end{array}$ & Test Result & Standard & Information \\
\hline Mud content & $4.50 \%$ & $\begin{array}{c}\text { Maks. } 5 \\
\%\end{array}$ & $\begin{array}{c}\text { MEET } \\
\text { REQUIREMENTS } \\
\end{array}$ \\
\hline $\begin{array}{l}\text { Bulk Specific } \\
\text { Gravity }\end{array}$ & 2.464 & & \\
\hline $\begin{array}{l}\text { Bulk Specific } \\
\text { Gravity SSD }\end{array}$ & 2.532 & $2.5-2.7$ & $\begin{array}{c}\text { MEET } \\
\text { REQUIREMENTS } \\
\end{array}$ \\
\hline $\begin{array}{l}\text { Apparent } \\
\text { Specific Gravity }\end{array}$ & 2.642 & & \\
\hline Absorption & $2.73 \%$ & & \\
\hline $\begin{array}{l}\text { Fine Grain } \\
\text { Modulus }\end{array}$ & 3.019 & $2.3-3.1$ & $\begin{array}{c}\text { MEET } \\
\text { REQUIREMENTS } \\
\end{array}$ \\
\hline
\end{tabular}


While testing for split coarse aggregate (broken stone) used in this study includes specific gravity testing, gradation of coarse aggregate, and wear (abrasion)

Table 2: Results of Rough Aggregate Testing

\begin{tabular}{|c|c|c|c|}
\hline Types of Testing & $\begin{array}{c}\text { Test } \\
\text { Result }\end{array}$ & Standard & Information \\
\hline $\begin{array}{c}\text { Bulk Specific } \\
\text { Gravity }\end{array}$ & 2.461 & & \\
\hline $\begin{array}{c}\text { Bulk Specific } \\
\text { Gravity SSD }\end{array}$ & 2.530 & $2.5-2.7$ & $\begin{array}{c}\text { MEET } \\
\text { REQUIREMENTS }\end{array}$ \\
\hline $\begin{array}{c}\text { Apparent Specific } \\
\text { Gravity }\end{array}$ & 2.644 & & \\
\hline Absorption & $2.81 \%$ & & \\
\hline $\begin{array}{l}\text { Fine Grain } \\
\text { Modulus }\end{array}$ & 6.960 & $5-8$ & $\begin{array}{l}\text { MEET } \\
\text { REQUIREMENTS }\end{array}$ \\
\hline Abrasion & $22.26 \%$ & $\begin{array}{l}\text { Max. } 50 \\
\%\end{array}$ & $\begin{array}{l}\text { MEET } \\
\text { REQUIREMENTS }\end{array}$ \\
\hline
\end{tabular}

From Table 2, the gross aggregate grading above can be described the grading graph along with the gradation limit required by ASTM C.136-05 as follows:
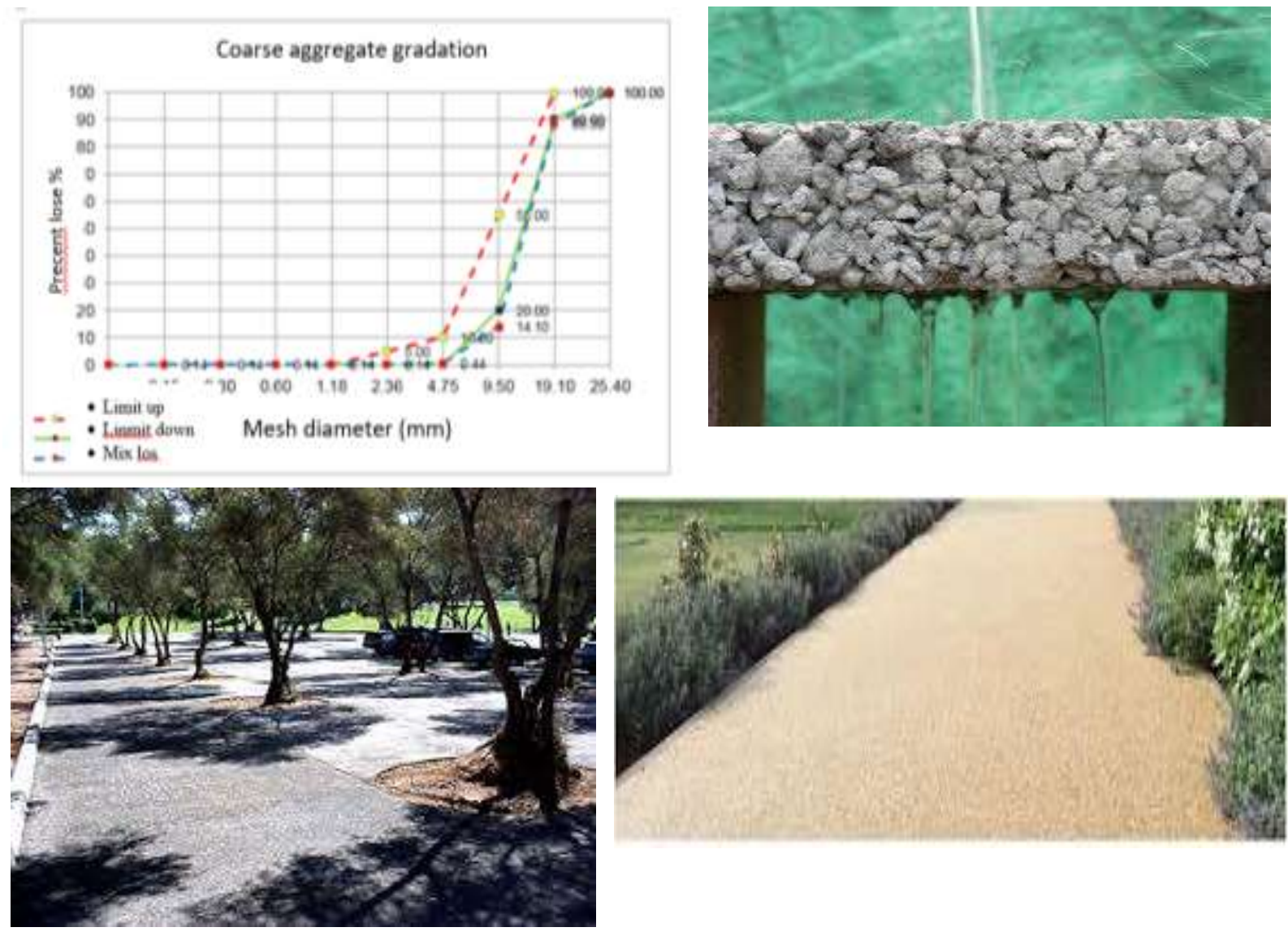

Figure 1. Sample Porous concrete

Infrastructure development often forgets the environment so that it disrupts the environment itself. This research is trying to encourage people to behave to protect the environment by using porous concrete, which can absorb much water to maintain groundwater conditions. 


\section{Conclusion}

From the test results, data analysis and discussion can be concluded as follows:

1. The more coarse aggregate used in making concrete, the smaller the value of the slump. That is because the absorptive capacity (absorption) of coarse aggregate is low so that the water that should be used for pasta will be reduced more when the aggregate is discharged. This situation causes the incisiveness of stirring concrete, and the slump value is also good.

2. From the results of compressive strength testing at the age of 7 days that concrete with stone ash variation of $44 \%$ gives a maximum compressive strength value, among other variations of stone ash, by $24.30 \mathrm{MPa}$. Then the compressive strength at the age of 14 days with a variation of stone ash by $44 \%$ gives a maximum compressive strength value, among other variations of stone ash by $28.51 \mathrm{MPa}$. Moreover, at the age of 21 days, concrete with stone ash variation of $44 \%$ gives a maximum compressive strength value, among other rock ash variations of $30.78 \mathrm{MPa}$.

3. The use of stone aggregates with a variation of more than $44 \%$ increases the compressive strength of concrete because, with more stone aggregates, it causes water to absorb a lot of rock ash so that in the process is difficult and less concrete density.

4. By using porous concrete changes, the protection of the community will care about environmental sustainability

\section{References}

Alhabeeb, M.J. (2019). Price Discrimination as a Marketing Strategy. International Journal of Marketing Studies, 11(4), 1-15.

Hardagung, H.T., Sambowo, K.A., \& Gunawan, P. 2014. Study of slump value, compressive strength and modulus of concrete elasticity with additives of ash stone paras filler. Matriks Teknik Sipil, 2(2), 131-137. (translated from Indonesia: Kajian nilai slump, kuat tekan dan modulus elastisitas beton dengan bahan tambahan filler abu batu paras. Matriks Teknik Sipil, 2(2), 131-137).

National Standardization Agency in Indonesia. (1992). Quality and how to concrete aggregate test. SNI 03-1750-1990. (translated from Indonesia: Agregat beton, Mutu dan cara uji. SNI 03-1750-1990).

National Standarization Agency in Indonesia. (2000). Procedure for making normal concrete mixed plans. SNI 03-2834-2000. (translated from Indonesia: Tata cara pembuatan rencana campuran beton normal. SNI 03-2834-2000).

Widodo, S., Sentosa, A., \& Pusoko, P. (2003). Utilization of ash stone waste as fillers in the production of self-compacting concrete. Jurnal Ilmiah Fakultas Teknik Universitas Negeri Yogyakarta. Yogyakarta. (translated from Indonesia: Pemanfaatan Limbah Abu Batu Sebagai Bahan Pengisi Dalam Produksi Self-Compacting Concrete. Jurnal Ilmiah Fakultas Teknik Universitas Negeri Yogyakarta. Yogyakarta. 